\title{
Chapter 8 \\ Managing the Crisis in Greece: \\ The Missing Link between External \\ Conditionality and Domestic Political \\ Economy
}

\author{
Dimitris Katsikas and Pery Bazoti
}

\begin{abstract}
The handling of the Greek crisis was not successful. Despite the sacrifices that the Greek people had to endure, the country's structural problems both in the public sector and the economy have not been resolutely resolved. This chapter offers an explanation for this failure. The main idea is to connect the externally imposed policy conditionality, with the particular characteristics of Greece's domestic political economy, seeking to integrate an analysis of impediments and opportunities for structural reform. While the literature on external institutional constraints emphasizes the possibility for achieving convergence, the institutionalist literature points towards divergence among national political economies, as institutional change and policy performance are conditioned by crucial intervening variables, namely, aspects of the domestic institutional infrastructure. In this context, Greece is a paradigmatic case of long-delayed or stalled reforms despite external pressures that promoted them. While most attention has been paid to the weaknesses of the EMU, this analysis' emphasis is on the role of crucial domestic factors. The analysis takes place in three steps: (a) the outline of Greece's institutional profile and growth trajectory based on an analysis of formal and informal domestic institutions; (b) the description and analysis of the design, implementation and impact of the adjustment programs; and (c) in view of (a) and (b) an assessment of whether the adjustment programs implemented in Greece took into consideration the characteristics of the country's political economy, and how and to what degree the failure to do so accounts for their results.
\end{abstract}

D. Katsikas $(\square)$

National and Kapodistrian University of Athens and Hellenic Foundation for European and

Foreign Policy (ELIAMEP), Athens, Greece

e-mail: dkatsikas@eliamep.gr

P. Bazoti

Hellenic Foundation for European and Foreign Policy (ELIAMEP), Athens, Greece

(C) The Author(s) 2021

B. De Souza Guilherme et al. (eds.), Financial Crisis Management and

Democracy, https://doi.org/10.1007/978-3-030-54895-7_8 


\section{Introduction}

Greece has undergone a deep, long-lasting crisis with unprecedented consequences for its political and socio-economic system. Already before the onset of the crisis, Greece was facing a mounting public debt and a number of structural economic deficiencies. When in 2009, revelations about Greece's unexpectedly high fiscal deficit became known, the resulting loss of credibility, in combination with the country's fiscal and economic woes and international investors' low risk appetite in the aftermath of the global financial crisis, shut the country out of the markets forcing the Greek government to make an official request for aid. On 2 May 2010, Greece signed a bailout agreement for a 3-year, €110 billion loan, provided by the Eurozone member-states and the International Monetary Fund (IMF). The agreement came with strict conditionality in the form of a comprehensive policy program (Memorandum of Understanding (MoU)) that would be supervised by the so-called Troika (representatives of the IMF, the European Commission and the European Central Bank (ECB)).

The program called for an extremely harsh front-loaded austerity policy. The aim was to eliminate the deficit and achieve a sustainable primary surplus, in order to ensure the sustainability of public debt. At the same time, the memorandum required an extraordinary number of major structural reforms to streamline public administration and improve the economy's international competitiveness. However, things did not develop as predicted. The aggressiveness of fiscal adjustment led the Greek economy into deep recession, which in turn undermined the government's fiscal consolidation efforts, leading to new measures and plunging the country into a downward economic spiral (Katsikas 2012).

The second bailout agreement, signed in early 2012, did nothing to change the mood in a country that found itself in a desperate social, economic and political situation. Thousands of businesses had gone bust, while unemployment reached $22 \%$ in the first quarter of the year. Frustration and anger simmered among the population. These feelings were openly vented at the elections of May, which changed fundamentally the political map of Greece. The once mighty, socialist PASOK, which had come to power in the October 2009 elections and had handled the crisis until that point, was relegated to third place, losing more than 30 percentage points in the polls. New Democracy, PASOK's centre-right counterpart, did not fare much better; while taking first place, it recorded its worst electoral result ever. The winners of the election were radical parties on the left and the right, united by their opposition to the bailout agreement and the memorandum. Particularly impressive was the performance of Syriza, a radical left-wing party, which took second place. The transformation of the Greek political scene was completed in January 2015 when SYRIZA won an early election and formed a coalition government with AN.EL., a populist, nationalist and ultra-conservative right-wing party.

The new government embarked on a new and ambitious negotiation with the creditors to formulate an entirely new type of agreement, outside the framework of the bailout programs. The handling of the negotiation by the Greek government was 
extremely poor (Katsikas 2016) and resulted in the debacle of the summer of 2015, when the deadline for reaching an agreement expired, leaving the country without a program, and therefore without funding and the banks without access to ECB's liquidity. ${ }^{1}$ Predictably, the country defaulted on an IMF payment, the banks were closed, and capital controls were imposed to prevent a bank run and capital flight. Despite the fact that the government won a hurriedly conducted referendum on a proposed draft agreement, with $61 \%$ of people rejecting the agreement (as was the government's proposal), the immediate danger of a Grexit ultimately led the government to sign a new bailout program. The new MoU continued where the previous left off, adding new austerity measures to make up for the lost time in 2015. Since 2017, the Greek economy has started growing again, and on August 2018, the third program was officially completed (the only one to be completed as planned). Although public finances have improved, the economic prospects of the country seem uncertain given the continued austerity of the post-bailout agreement with the creditors and the incomplete structural reforms program.

From this brief overview of the crisis, it is evident that its handling was not successful. The fiscal balance has been restored, but this came at a great economic and social cost; meanwhile many of the country's structural problems both in the public sector and the private economy remain unresolved. This chapter seeks to offer an explanation for this failure. The main idea is to connect the externally imposed policy conditionality, with the particular characteristics of Greece's domestic political economy, seeking to integrate an analysis of impediments and opportunities for structural reform. While the literature of external constraints emphasizes the potential for convergence, the institutionalist literature stresses the divergence among national political economies, as institutional change and policy performance are conditioned by crucial intervening variables, namely, aspects of the domestic institutional environment, including norms and practices.

The analysis will take place in three steps: (a) the establishment of Greece's political economy profile and growth trajectory before the crisis; (b) the description and analysis of the design, implementation and impact of the adjustment programs; and (c) in view of (a) and (b) an assessment of whether the adjustment program implemented in Greece took into consideration the country's institutional specificities and how to what degree the success/failure of doing so can account for the program's results.

\footnotetext{
${ }^{1}$ For a different view from the man who handled the negotiation, see Varoufakis (2018), and for a journalistic account that tells a very different story from that of Varoufakis, see Dendrinou and Varvitsioti (2019).
} 


\section{The Domestic Politico-Economic System}

The present Greek political system was mainly consolidated in Metapolitefsi, a term referring to the period after the fall of the military junta in 1974 and the reestablishment of democracy. During this period, two parties dominated the political scene, the socialist-democratic PASOK and New Democracy on the centre-right. The two parties alternated in power, forming strong single-party governments, with smaller parties having a marginal role in governmental politics. During these years, the majority of the electorate was siding with one of the two dominant parties regardless of their policies. This kind of partisan identification reflected events of the Greek political history, mainly the Civil War of 1944-1949, when political divisions deteriorated to a prolonged armed conflict, a painful legacy whose shadow still lingers today.

Under such polarized circumstances, the formation of single-party governments has been relying mostly on the 'moving' voters between the two parties. Despite being a minority in numbers, this part of the electorate has proven to be a critical driver of elections' outcomes. Hence, political parties have traditionally sought to acquire control of this minority by creating and maintaining an extensive network of preferential relationships with potential voters, in exchange for their vote. Clientelism became the foundation of the Greek party system, in the form of privileges granted in specific social groups and/or areas, and permeated the functioning of the state and the private economy. State power has been used by political parties as a means to extend benefits and privileges in exchange for electoral support, resulting in the state's haphazard expansion into all areas of public life and the creation of what has been termed 'bureaucratic clientelism' (Lyrintzis 1984) or 'clientelistic state' (Sotiropoulos 2001).

This came mainly in the form of seeking employment in the public sector; a job in the public sector became exceptionally popular among citizens as it offered the advantages of job security and a relatively high wage. Consequently, it quickly became the subject of exchange in return for votes, at the expense of public finances. Although not disproportionally bigger than other OECD countries' public sectors, the Greek public sector has been more expensive, due to both higher remuneration costs and its inefficient operation (Ladi and Katsikas 2017). The fiscal impact of clientelism is well illustrated by the presence of politically induced cycles in Greece's public finance. A recent study by Chortareas et al. (2018) reveals that during election years in the era of Metapolitefsi, there was an annual increase in governments' expenses by $1.7 \%$ and a deterioration of the primary balance of almost $3 \%$.

The favourable conditions for civil servants were not unrelated to the presence of their particularly strong trade union, ADEDY. Before the crisis, trade unions, in the form of formal organizations and institutions, were the sole actors of an underdeveloped civil society. Confederations of unions, and mainly ADEDY, or GSEE, representing employees of large private sector companies, had an active involvement in the political system and had established a quid pro quo bond with incumbent 
governments. This comes as no surprise if one considers that both political parties have infiltrated the labour and student movements (Sotiropoulos 2018).

Accordingly, a distorted collective bargaining process was forged. Unions pushed towards policies that were not aligned with the economic prospects and abilities of the state and the economy. General strikes and street protests were often used as a lever of pressure against incumbent governments. Such practices created an ineffective and fragmented labour market as the labour costs rose disproportionally to labour productivity and divisions between 'insiders' from influential labour unions and under-represented 'outsiders' (e.g. employees of small and medium-sized private businesses and the self-employed) were deepened. In these circumstances, undeclared work thrived. Clientelism ended up substituting social insurance and meritocracy and left no room for the development of a modern welfare system.

The private economy could not remain unaffected in these conditions. Growth was mainly based on domestic consumption of non-tradables fuelled by domestic and foreign credit as a result of the low interest rates that followed Greece's accession to the EMU and the liberalization of the Greek but also the European and international financial systems. This led to Greece's twin deficits. On the one hand, successive governments' 'largesse' led to a derailment of public finances, driving the fiscal deficit to an unprecedented $15.2 \%$ of GDP in 2009. On the other hand, Greece imported a large part of what it consumed, a tendency which led to an increasing current account deficit, which peaked at 14.9\% in 2008.

The economy remained closed and introvert; exports of traded goods contributed less than $10 \%$ of GDP before the crisis, mostly in sectors of low technological content and value added (Zografakis and Kastelli 2017), while Greece ranked last in attracting Foreign Direct Investment (FDI) in the EU-27 (Papazoglou 2014). This situation was partly due to inflated labour costs, as explained above; the loss of competitiveness, however, was also due to other factors, such as the small size of Greek businesses and the low levels of competition in domestic product (goods and services) markets (Papazoglou 2014; Vettas and Kouranti 2014). Many of these problems were due to the adverse regulatory environment in Greek product and labour markets, which suffered from excessive and low-quality regulation, which, more often than not, served particular private interests. According to the Index of Economic Freedom (2018), for the period 1995-2008, the Greek economy moved between the moderately free and mostly unfree categories.

Indicative, and a direct result of the lack of openness and the close embrace between political power and economic interests, was the pervasive presence of corruption. The average score of the Corruption Perceptions Index of Transparency International (2018) for the years 2000-2009 was 4.4, with 0 standing for highly corrupt and 10 for 'clean' countries. At 2009, the year of the outbreak of the crisis, Greece had a score of 3.8 and ranked 94th among 180 countries.

Despite the absence of high-quality inclusive institutions, Greece managed to grow. After a slowdown of the growth rate in the 1970s and a drawn-out economic crisis during the 1980s, the economy recorded substantial growth from the mid1990s up until the crisis; according to Eurostat data, between 1995 and 2007, Greece's GDP was growing by $3.74 \%$ annually, a growth rate well above the EU 
and Eurozone averages. However, this growth had a plateau given that it was driven by the effects on consumption and construction due to the partial liberalization of the economy, particularly in the financial system, during an era of global prosperity and de-regulation and the constant flow of EU structural funds. Favourable external conditions sustained the distortions and weaknesses of the Greek political and economic institutions, creating a socioeconomic framework which was at the same time ineffective and stable but also highly vulnerable to abrupt changes in the external environment.

\section{External Conditionality: An Overview of the Policy and Institutional Aspects of the Adjustment Programs}

The main objectives of the three Economic Adjustment Programs were to restore fiscal sustainability and international competitiveness and to secure the stability of the financial system. To achieve these objectives, the MoUs agreed between Greece and its creditors included a wide array of measures both in the expenditure and revenue side of the government's budget, a major structural reforms' program in both the public administration and the private economy and an ambitious plan of privatizations.

The focus of the first program was on restoring fiscal sustainability and therefore promoted tax increases and horizontal cuts in government expenses (e.g. through reductions in salaries, pensions and social benefits). These policies had an immediate effect, and by the end of 2010 the government was able to boast a spectacular reduction of the fiscal deficit by more than 5 percentage points. However, further progress in reducing the fiscal deficit, but also in the crucial task of restoring the country's competitiveness, required complex, difficult and time-consuming structural reforms in both the state apparatus and the private economy. In addition to their complexity, these reforms elicited strong and well-organized opposition from interest groups that stood to lose from their implementation. As a result, the structural reforms' program soon came to a standstill. At the same time, despite the improvement in public finances, the deep recession meant that public debt as a percentage of GDP rose to $172 \%$ in 2011, fuelling fears about an impeding Greek bankruptcy. Under these circumstances, markets' expectations regarding the country's economic course sank, and the sovereign debt crisis became a crisis of the banking sector as the Greek banks were heavily exposed to Greek public debt. The Troika gradually and reluctantly accepted the necessity of negotiating a second bailout agreement with additional funds, accompanied by an agreement to reduce Greek debt to more sustainable levels.

The second bailout program was signed in March 2012 by an interim three-party coalition government under Lucas Papademos, former ECB Vice President, which had formed following a governmental crisis in late 2011. The funds made available through the second bailout agreement were $€ 174$ billion; $€ 117.8$ billion were related 
to the bail-in of the private sector creditors (PSI), while the remainder were meant to cover the operational financing needs of the Greek government and the repayment of public debt falling due (European Commission 2012). The terms of the second loan agreement were more favourable than the first (whose maturity was also extended); the new loans had long maturities (15-30 years, with a grace period of 10 years for the European loan) and a reduced interest rate margin. At the same time, the PSI deal reduced the privately held Greek debt by $€ 106$ billion, while extending the remainder for up to 30 years, imposing on investors losses of up to $75 \%$ in terms of net present value.

Despite the aforementioned benefits, the agreement sparked a domestic political crisis, due to the new round of measures mandated by the memorandum that accompanied the loan agreement. More specifically, the memorandum dictated a new round of austerity measures including the abolition of most tax exemptions, a new round of reductions in salaries, pensions and benefits and more cuts in several areas of public spending. However, what caused the greatest consternation were the interventions in the labour market. The minimum wage was reduced by $22 \%$ and by an additional $10 \%$ for young people up to the age of 25 . At the same time, the new memorandum abolished the status of existing collective agreements as a minimum framework of reference for labour rights and wages, until new agreements were negotiated between employers and employees, opening thus the way for the replacement of sectoral agreements by company-level and individual agreements. The memorandum also stipulated that personnel in the public sector would be reduced by at least 150,000 until 2015 . Finally, the agreement included an extremely ambitious privatization plan which was originally thought to bring to the public coffers $€ 50$ billion, a projection that proved wildly optimistic.

The government coalition of the radical left SYRIZA and the nationalist rightwing AN.EL. signed the third Economic Adjustment Program after a period of dramatic and ultimately failed negotiations with the country's creditors, which led to the highly controversial and polarizing referendum of June 2015. The third loan agreement, signed in August 2015, was in line with the previous ones, adding new measures to make up for the off-track course of the Greek economy during the negotiations' period. The new reform agenda was based on four main pillars. First, the restoration of fiscal sustainability with a gradual increase of primary surplus targets to $3.5 \%$ of GDP from 2018 onwards through a set of upfront fiscal measures such as VAT increases, a comprehensive pension reform meant to reduce the fiscal burden of future pensions and measures to enhance tax compliance. To ensure compliance with the targets, the first program review in May 2016 added a mechanism which automatically triggered additional measures in case of fiscal imbalances. Second, the restoration of financial stability by addressing in a decisive way the issue of non-performing loans (NPLs) and by recapitalizing the banks by end-2015. Third, in order to strengthen growth and restore competitiveness, Greece undertook the responsibility to implement a new privatization plan, policies that would support further investments as well as a wide range of reforms in the labour and product markets. Finally, a key priority was the creation of a modern structure in public administration with measures aiming at enhancing its efficiency, fighting corruption 
and ensuring the independence of key institutions such as the revenue administration and the statistics institute (European Commission 2016).

\section{Assessing the Compatibility of the External Constraint and Domestic Institutions}

The policy conditionality promoted through the MoUs had all the characteristics of the 'traditional' IMF recipe: fiscal consolidation, liberalization of the economy and, due to the inability to engage in external devaluation, labour market reforms aimed at internal devaluation. This policy program failed to adequately take into account the particular characteristics of Greece's political economy.

First, while there is no doubt that a certain degree of austerity would have to be implemented in the case of Greece, given its huge fiscal deficit, the fiscal consolidation program was extremely ambitious. The first MoU called for an array of fiscal measures with a view to reducing the fiscal deficit by $11.2 \%$ of GDP by 2013, that is, a reduction of more than $3 \%$ of GDP per year, with primary surpluses projected thereafter. This kind of adjustment is not unprecedented but has been achieved in only a handful of cases, typically not in circumstances of deep recession, which Greece found itself in already from 2008, and in countries with very different characteristics from Greece, namely, open and extrovert economies (Anastasatou 2017). The fiscal consolidation program underestimated the dependence of the Greek economy on the state budget and domestic consumption and therefore the consequences that a drastic reduction in state spending and disposable income, as a result of austerity, would have on economic growth. Indeed, the program's projections were constantly and overwhelmingly optimistic regarding a number of macroeconomic variables, such as private consumption and investment and therefore GDP growth (Petralias et al. 2013).

The unprecedented decline of economic activity and the consequent dramatic increase in unemployment (Fig. 8.1) translated into reduced tax revenues and social security contributions, at a time that the government bill for unemployment and other social benefits was increasing. As a result, fiscal targets were missed, which led to the adoption of new austerity measures to make up for the deviations, which in turn deepened the recession. ${ }^{2}$ This downward economic spiral derailed the creditors' plans and made obvious the need for a second MoU, which however continued on the same policy path, as did the third.

In addition to miscalculating the impact of austerity on the Greek economy, given its structural characteristics, it seems that the designers of the MoUs also ignored two other features of the Greek political economy. First, the dependence of

\footnotetext{
${ }^{2}$ Governments also tried to meet the fiscal targets by reneging on their own obligations, by delaying tax returns and payments towards domestic suppliers and by cutting down repeatedly the public investment account in the budget; these tactics deprived the economy from much-needed liquidity, deepening the downward economic spiral.
} 


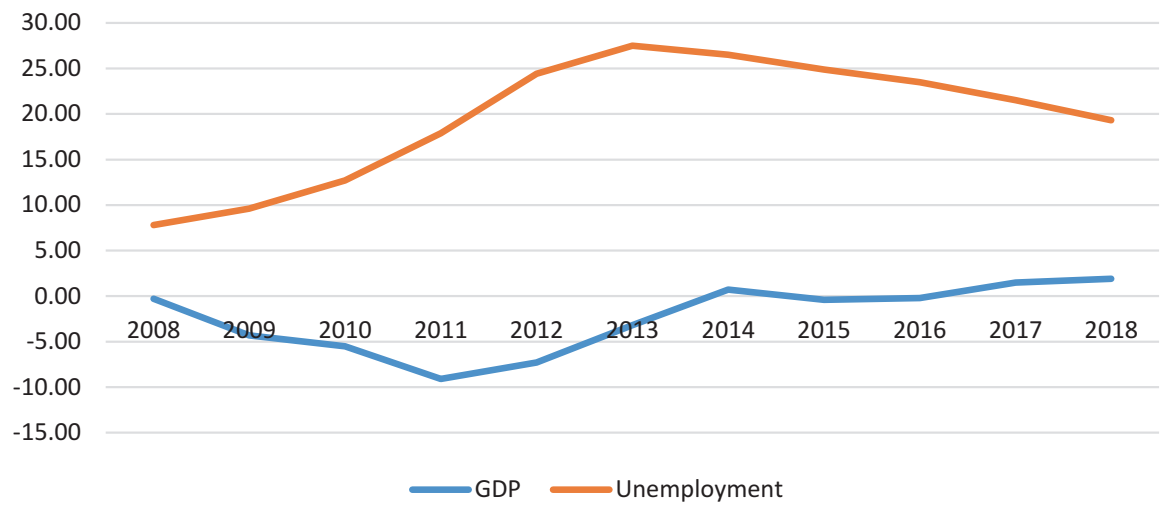

Fig. 8.1 GDP growth rate and unemployment rate (Source: ELSTAT)

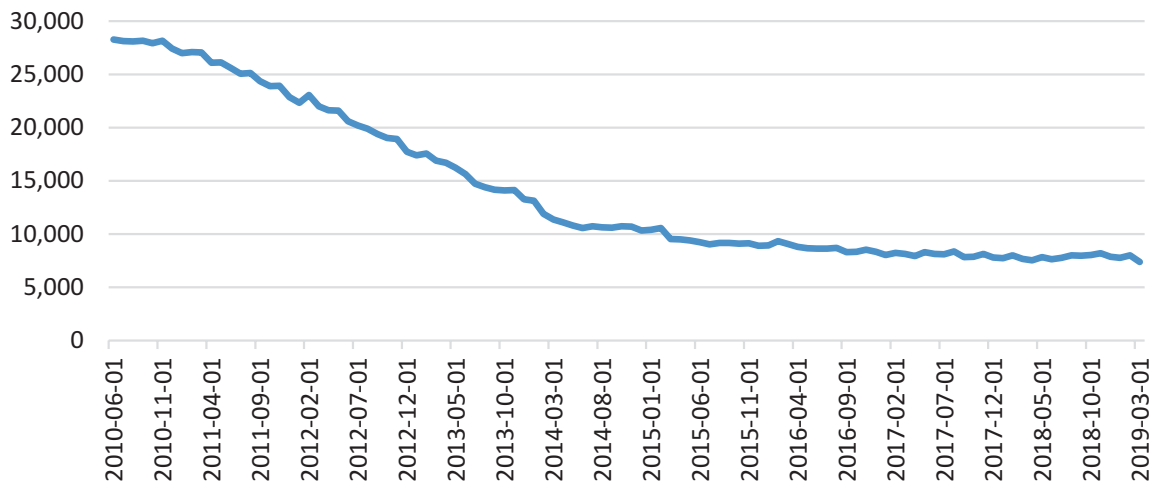

Fig. 8.2 Volume of new bank euro-denominated loans to non-financial corporations, Greece, June 2010-February 2019 (in millions of euros). (Source: Bank of Greece)

both the private economy and the state on the domestic banking system for funding. Given the banks' high exposure to Greek public debt, the impact of the sovereign debt crisis on Greek banks was tremendous as it cut them off from the interbank market and imposed on them substantial losses through the PSI. Moreover, as the economy deteriorated and uncertainty rose, there was a massive outflow of deposits and a dramatic increase in NPLs. ${ }^{3}$ The resultant credit crunch left Greek businesses not only without access to capital for investment purposes but lacking even working capital to meet their daily operational needs (see Fig. 8.2). In the rare cases that

\footnotetext{
${ }^{3}$ According to the Bank of Greece (2015), banks' non-performing exposures (a measure similar to NPLs) in the first quarter of 2015 accounted for $40.8 \%$ of all loans and amounted to more than 100 bn euros.
} 
funding was available, the high cost of capital discouraged most businesses from borrowing, despite their dire circumstances. ${ }^{4}$

Secondly, the MoUs did not take into account the limited support available through the weak and fragmented Greek welfare state, which traditionally catered mostly to the needs of pensioners. The insufficiency of social benefits (including unemployment benefits) meant that many people went for years with minimal or even no support at all..$^{5}$ As a result, the economic crisis led to social degradation (Matsaganis and Leventi 2014; Katsikas et al. 2015), as poverty rates soared to unprecedented levels (Fig. 8.3). The severe social crisis not only impeded economic recovery but fuelled even more the social and political reaction against the continued austerity policies and the MoUs in general, raising further the political cost of their implementation.

While austerity was driving the Greek economy into depression, an ambitious program of structural reforms was also under way. It had two main objectives: (a) to improve the effectiveness and efficiency (in fiscal terms) of the public administration and (b) to restore the economy's international competitiveness. Pursuing the first objective called for a broad array of structural reforms with a fiscal impact, such as the establishment of a single payments authority for all public servants, a complete overhaul of the financial administration of the Greek National Health System, an overhaul of the Greek tax and pension systems and even reforms in the country's judicial system.

The reforms promoted were appropriate and much needed in most of the cases; however, their design and implementation were far from optimal, partly because

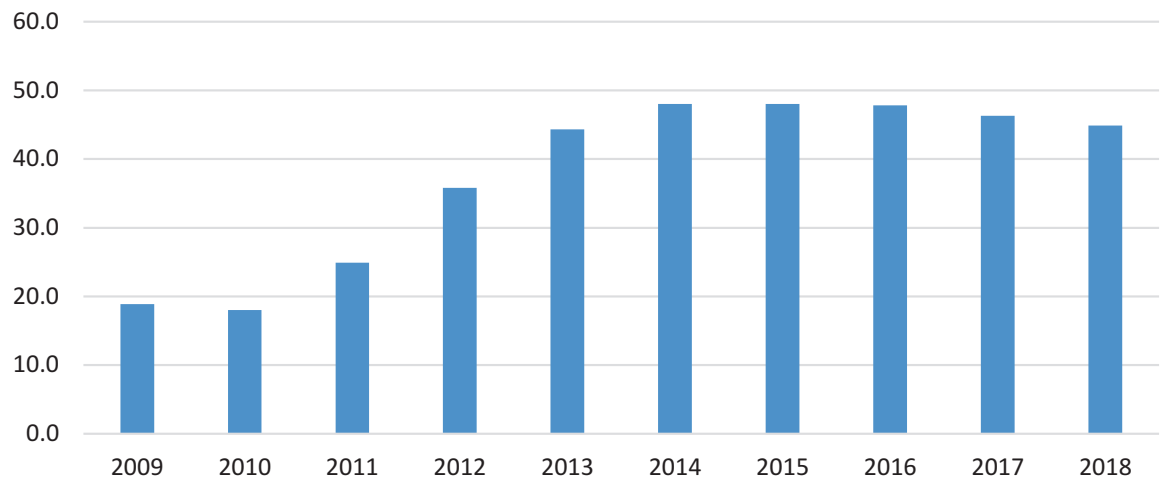

Fig. 8.3 At-risk-of-poverty rate anchored at a fixed moment in time (2008) by age and sex, Greece. (Source: Eurostat - EU-SILC Survey)

\footnotetext{
${ }^{4}$ Between the summer of 2010 and October 2015, the average interest rate for credit lines to nonfinancial corporations ranged between 6 and $8 \%$ (Bank of Greece). It is worth noting that for most of this period ECB's official rate was below $1 \%$.

${ }^{5}$ It is telling that during the crisis, typically less than $15 \%$ of the unemployed received unemployment benefits.
} 
they did not adequately take into account the institutional capacity and characteristics of the Greek public administration. A first problem was the sheer size and scope of the reform program, designed to be implemented in a relatively short period of time, which strained the limited resources of an already weak administration (Spanou 2018). This led to outright failures to promote certain reforms and partial and delayed progress in the implementation of others. The structural weaknesses of the public administration were compounded by the focus on fiscal consolidation, which affected adversely the priorities of many reforms (Spanou 2018).

Secondly, the design and handling of administrative reforms were often driven by a misunderstanding of the broader normative and political framework surrounding the operation of public administration. This became clear with one of the most controversial reforms, a commitment to reduce the number of public servants by 150.000 by 2015 . Leaving the arbitrariness of that number aside, the reform was based more on calculations about its fiscal impact and the desire to send a 'message' about the creditors' determination to end the political protection enjoyed hitherto by civil servants. The announcement of the reform served only to create insecurity to civil servants amidst a deep economic crisis, which created a political backlash both by the public servants' unions and the opposition parties. Threatening massive layoffs in the public sector ignored the dependence of the ruling political elites on the goodwill of civil servants to produce results in an administration which lacked clear, common and high-quality operating procedures but also violated a 'taboo' of Greek society, which views lay-offs as a means of restoring efficiency, as ethically reprehensible. While the government was quick to give public assurances that personnel reductions would happen without resorting to lay-offs, the political backlash sidetracked other necessary reforms, such as the introduction of a personnel evaluation system or a mobility scheme.

Similar problems emerged with reforms intended to restore the international competitiveness of the Greek economy as the internal devaluation approach ignored the structural and institutional characteristics of the Greek economy. The small export sector, specializing mostly in agricultural and low-technology products, could not capitalize on lower labour costs to a degree that would have a significant impact on the economy. Indeed, in the early years of the crisis, there was hardly any increase in exports despite the fact that labour costs had been reduced considerably (Zografakis and Kasteli 2017). Since 2015, exports have been gradually increasing but not at a pace sufficient to sustain economic recovery, and the Greek economy is still a long way from being considered an open and extrovert economy (Fig. 8.4).

Indeed, given the structural and institutional characteristics of the Greek economy, such as the small scale of production, specialization in low value-added activities, high dependence on imports for intermediate products and the bureaucratic burden which impedes competition and productive investment, the belief that the reduction of labour costs alone would be sufficient to substantially improve the competitiveness of the Greek economy should be considered naïve at best.

Given these problems, a more rational scheme would involve early and ambitious reforms in the business environment and the product markets, before moving to labour market reforms. Such a reform sequence is compatible with the findings of 
$25,000.0$

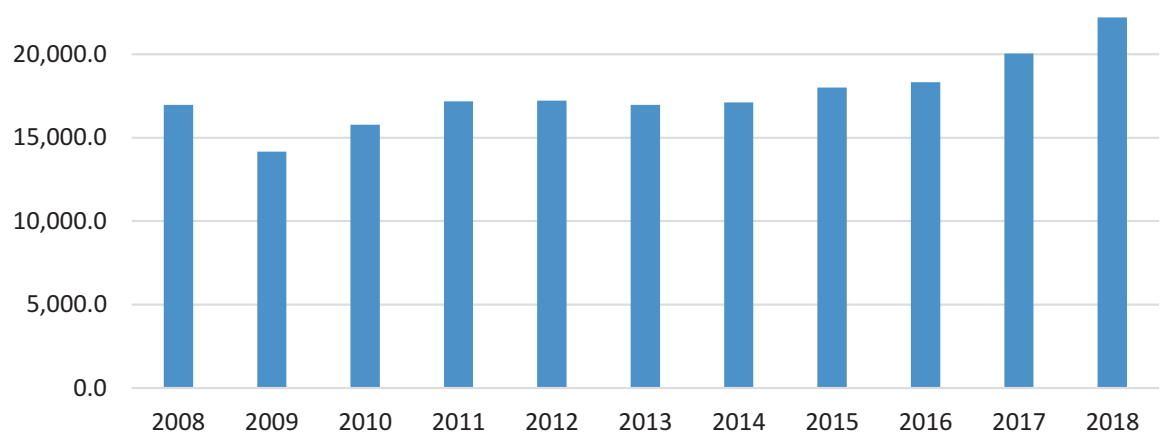

Fig. 8.4 Exports of traded goods (excluding ships and fuel), 2008-2018 (in millions of euros), Greece. (Source: Bank of Greece)

empirical bibliography internationally (Bouis et al. 2012) but also for the case of Greece (Petralias and Katsikas 2018). Unfortunately, significant reforms in the product markets, such as the so-called OECD's toolkit, ${ }^{6}$ which has been shown to have affected positively employment and prices (Petralias et al. 2018), were only introduced in 2014, as was the crucial reform of the regulatory framework for the licensing of productive investments, a reform which has yet to be completed.

\section{Conclusions}

Greece's crisis was one of the deepest and longest-lasting crises in the post-war period internationally. During a period that lasted more than 8 years, the country implemented three consecutive adjustment programs which imposed strict austerity policies and a host of ambitious reforms. While the fiscal balance has been restored, the economic and social cost incurred were tremendous, as more than $25 \%$ of GDP was lost and unemployment and poverty rates soared to unprecedented levels. At the same time, the sustainability of Greece's debt has not been restored, because the huge drop in GDP has increased the ratio of debt to GDP well above its pre-crisis levels (181\% in 2018). Moreover, despite progress in many areas of public administration and the regulation of the private economy, some of Greece's most important structural problems remain unresolved. These problems continue to undermine both the efficient and effective operation of the public administration and Greece's

\footnotetext{
${ }^{6}$ The 'OECD Competition Assessment toolkits' are packages of measures that aim to reduce the regulatory burden in product and service markets, based on comprehensive studies of several key sectors. In the Greek programs, there were three waves of such studies, in 2013, 2014 and 2016. In total, the toolkits identified 1276 regulations which inhibited competition and proposed 773 measures relating to 14 major sectors of the Greek economy (SEV 2016).
} 
potential to become an extrovert, competitive economy. The country has gone through a period of tremendous social and political unrest, which led to a radical change of its political landscape and at times threatened Greece's place in the Eurozone.

On balance therefore, one would be hard-pressed to argue that Greece's bailout has been a success story. One of the most important reasons for this failure has been the lack of ownership of the policies promoted. This in turn is due not only to the character of the policies themselves (e.g. extreme austerity) but also to the shallow and incomplete understanding of Greece's political economy. The policies promoted magnified the economic and social crisis as they failed to take into consideration the public administration's and the economy's structural and institutional features. Beyond its adverse economic impact, this failure also had significant political repercussions, as it allowed populist parties to take advantage of people's anger and frustration and dominate the political scene, increasing political uncertainty, undermining progress in much-needed reforms and ultimately delaying the country's exit from the crisis.

The creditors' attitude of zero tolerance for deviations from the program, which at times seemed to stem not only from ignorance but also ideological fixations, particularly on the crucial issue of austerity, did not facilitate incumbent governments' efforts. ${ }^{7}$ On the contrary, it fed social discontent both against the incumbent governments and the European Union. It is telling that, in 2018, following Greece's completion of the third adjustment program, three quarters of Greeks still did not trust the EU, the highest number among all member-states (Eurobarometer 90.3). All in all, it seems that too much economic, social and political capital was spent to achieve too little, too late.

\section{References}

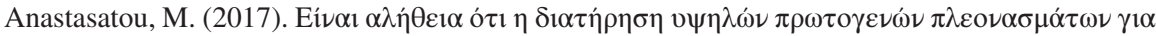

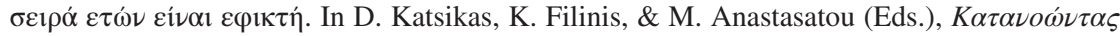

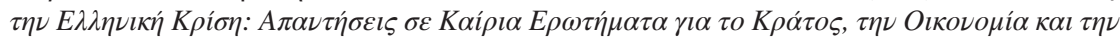

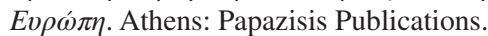

Bank of Greece (2015). Monetary Policy. Annual Report. Athens

Bouis, R., Causa, O., Demmou, L., Duval, R., \& Zdzienicka, A. (2012). The short-term effects of structural reforms: An empirical analysis. OECD Economics Department Working Paper, No 949.

Chortareas, C., Logothetis, V. E., \& Papandreou, A. A. (2018). Elections and opportunistic budgetary policies in Greece. Managerial and Decision Economics, 39(8), 854-862.

Dendrinou, V., \& Varvitsioti, E. (2019). The last bluff: How Greece came face-to-face with financial catastrophe \& the secret plan for its euro exit. Athens: Papadopoulos Publishing.

\footnotetext{
${ }^{7}$ That is not to say that incumbent governments always put in the required effort; governments seeking to reform the Greek state and economy would have to clash with a wide array of interest groups, turning in effect against their own political clients. In many cases, therefore, they chose to safeguard partisan interests, hoping to preserve some of their political capital.
} 
European Commission (2012). The Second Economic Adjustment Programme for Greece. Occasional Papers 94. Brussels.

European Commission (2016). Compliance Report: The Third Economic Adjustment Programme for Greece. First Review. June. Brussels.

Index of Economic Freedom (2018). Figure the data. https://www.heritage.org/index/visualize. Accessed 25 Apr 2018.

Katsikas, D. (2012). The never-ending greek crisis: A tragedy without a catharsis. Revista de Estudios Europeos, 60(Jul-Dec), 33-52.

Katsikas, D. (2016). An old crisis, a new government and the creditors: 'Plus ca change plus c'est la même chose'? In P. Morrilas \& T. Dokos (Eds.), Greece and the EU: Lessons from a longlasting crisis. Barcelona: CIDOB MonoFigures, Barcelona Centre for International Affairs.

Katsikas, D., Karakitsios, A., Filinis, K., \& Petralias, A. (2015). Social profile report on poverty, social exclusion and inequality before and after the crisis in Greece. Crisis Observatory and Hellenic Open University. http://crisisobs.gr/en/2015/01/ekthesi-gia-to-kinoniko-profil-tiselladas-se-schesi-me-ti-ftochia-ton-kinoniko-apoklismo-ke-tin-anisotita-prin-ke-meta-apotin-ekdilosi-tis-krisis/. Accessed 20 Sept 2019.

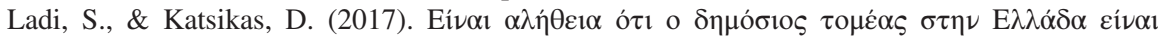

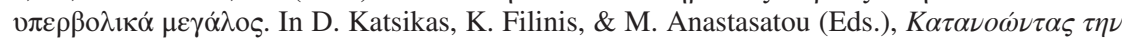

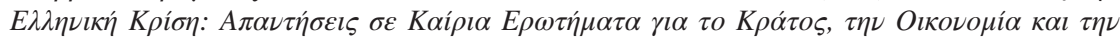

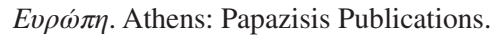

Lyrintzis, C. (1984). Political parties in the post-junta Greece: A case of "bureaucratic clientelism"? West European Politics, 7(2), 99-118.

Matsaganis, M. \& Leventi, C. (2014). Poverty and Inequality during the Great Recession in Greece. Political Studies Review, 12, 209-223.

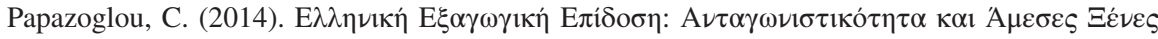

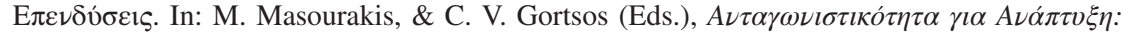

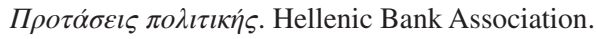

Petralias, A., Petros, S., \& Prodromidis, P. (2013). Greece in recession: Economic predictions, mispredictions, forecast suggestions and policy recommendations. Cyprus Economic Policy Review 7(2), 53-80.

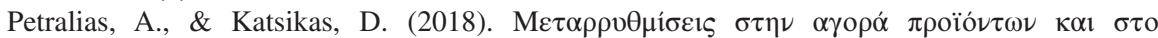

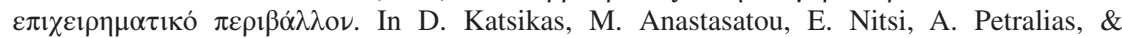

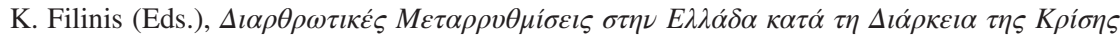

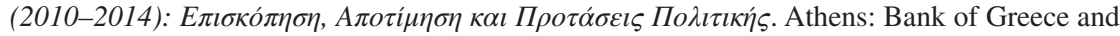
ELIAMEP.

Petralias, A., Anastasatou M., \& Katsikas, D. (2018). Balancing adjustment policies and structural reforms in Greece: the case of product markets. In P. Manasse \& D. Katsikas (Eds.), Economic Crisis and Structural Reforms in Southern Europe. London and New York: Routledge.

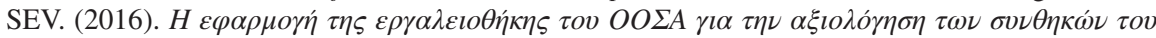

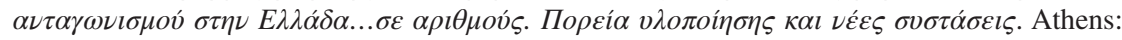
Business Environment Observatory, SEV.

Spanou, C. (Ed.) (2018). Reforms in Public Administration under the crisis: Overview, Description, Evaluation. Athens: ELIAMEP.

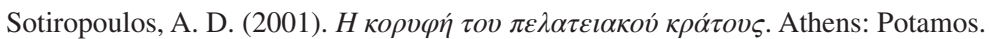

Sotiropoulos, D. A. (2018). A fragmented but strengthened civil society? In D. Katsikas, D. A. Sotiropoulos, \& M. Zafiropoulou (Eds.), Socioeconomic fragmentation and exclusion in Greece under the crisis. New York: Palgrave Macmillan.

Transparency International (2018). Corruption perceptions index 2000. https://www.transparency. org/research/cpi/cpi_2000/0. Accessed 15 Mar 2018.

Varoufakis, Y. (2018). Adults in the room: My battle with the European and American deep establishment. New York: Farrar, Straus and Giroux. 


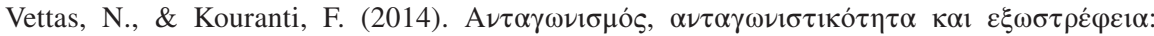

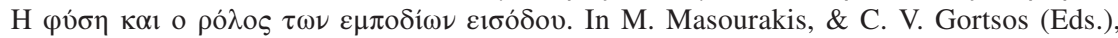

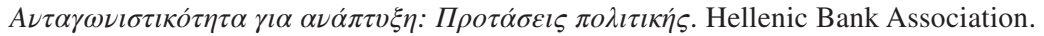

Zografakis, S., \& Kastelli, I. (2017). Is it true that reducing labour costs is sufficient to improve the competitiveness of the Greek economy? In D. Katsikas, K. Filinis, \& M. Anastasatou (Eds.),

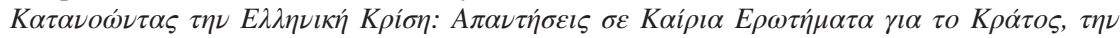

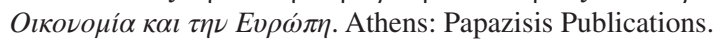

Open Access This chapter is licensed under the terms of the Creative Commons Attribution 4.0 International License (http://creativecommons.org/licenses/by/4.0/), which permits use, sharing, adaptation, distribution and reproduction in any medium or format, as long as you give appropriate credit to the original author(s) and the source, provide a link to the Creative Commons license and indicate if changes were made.

The images or other third party material in this chapter are included in the chapter's Creative Commons license, unless indicated otherwise in a credit line to the material. If material is not included in the chapter's Creative Commons license and your intended use is not permitted by statutory regulation or exceeds the permitted use, you will need to obtain permission directly from the copyright holder.

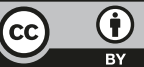

